\title{
THE REALITY OF THE LOCALITY: EXPLORING SPATIAL ASPECTS OF QUALITY OF LIFE IN GALWAY CITY, IRELAND
}

\author{
F. FAHY \& M. Ó CINNÉIDE \\ Department of Geography, National University of Ireland, Galway, Ireland.
}

\begin{abstract}
Quality of life is increasingly recognised as a vital component of sustainable urban development. Indicators are used to assess quality of life and to monitor progress towards sustainability over time. An emerging body of literature contends that these indicators need to be derived in close consultation with target populations in order to optimise the extent to which they capture the real determinants of quality of life in particular places. Furthermore, quality of life considerations vary significantly across urban neighbourhoods and consequently the spatial scale at which such studies are conducted may have significant implications for the results obtained. This study focuses on spatial variations in quality of life in Galway, a city of approximately 70,000 people, situated on the west coast of Ireland. Galway is reported as having an exceptionally high quality of life, however, significant variations are found to exist across city neighbourhoods. Factors contributing to this spatial pattern are explored in this paper. An important lesson emerging from this study is that quality of life indicators derived at the neighbourhood level are of utmost importance when assessing the reality of living in different urban settings.
\end{abstract}

Keywords: Ireland, quality of life indicators, scale, sustainable urban communities.

\section{INTRODUCTION}

Economic growth and development have taken place at an unprecedented rate in the Republic of Ireland, over the past decade or so. Impressive social and spatial transformations have accompanied this development. However, many issues surrounding quality of life are beginning to penetrate both popular and political discourse [1]. An international survey by the Economist Intelligence Unit using a Quality of Life Index which attempts to measure a nation's attractiveness as a place to live, on the basis of health (life expectancy at birth), quality of family life (divorce rate), job security (unemployment rate), gender equality (ratio of male to female earnings), community life and social cohesion (rate of attendance at church or trade union membership), material well-being (gross domestic product per person), climate and geography (geographical latitude), political freedom (index on political and civil liberties) and political stability and security (Economist Intelligence Unit's own ratings) placed Ireland to the fore of the 111 countries studied, primarily because the country 'successfully combines the most desirable elements of the new (high GDP per head, low unemployment, political liberties) with the preservation of certain cosy elements of the old, such as stable family and community life' [2]. Many commentators dispute the claim that the highest quality of life in the world is to be found in Ireland. It is argued that the national level quantitative rankings, such as that of the Economist, obscure many aspects of real life and that local level studies are required to adequately assess quality of life in a truly meaningful way. Economic, social and environmental problems such as spiralling house prices, loss of community identity, disappearance of green space in urban neighbourhoods and ever-increasing traffic jams are cited as evidence of the current reality in Ireland.

Quality of life in Galway City, one of Europe's fastest growing urban centres, situated on the west coast of Ireland is examined in this paper. The analysis is at the scale of the city as a whole but important variations between neighbourhoods are shown to exist. Drawing on an emerging body of international research that seeks to identify key factors impinging on quality of life at city and 
community levels [3, 4], the associated methodologies are modified and applied at the local scale in Ireland for the first time. The study is part of a wider project, funded by the Irish Environmental Protection Agency, which aims to develop tools to progress sustainability at the local level. This article is divided up into four sections. The first outlines theoretical underpinnings of research into quality of life and links to sustainable development. The research design, including a description of the case study city, and the characteristics and profiles of the five neighbourhoods that were surveyed within Galway City are presented in the second section. As the primary focus is on spatial variations in quality of life between neighbourhoods across one urban centre, the third section reports on survey results from the five neighbourhoods as well as results detailing overall life satisfaction in Galway City as a whole. The article concludes with a discussion of these findings and their implications for public policy.

\section{RESEARCHING QUALITY OF LIFE}

Quality of life is increasingly regarded as 'a part of the profile of a 'competitive city'; one that is successful in attracting the attention of capital' [5]. As cities around the world promote the goal of becoming a 'livable city', academic interest in quality of life in urban areas has grown significantly. Although often used to promote economic growth, quality of life is subject to change because of growth and development [6]. Measuring quality of life in cities typically involves the development of indicators which cover themes such as crime, healthcare, cost of living, etc. Formulating indicators gives rise to difficult questions relating to what should be incorporated as significantly influencing 'quality of life'. One reason for this is that there are a large number of diverse definitions of quality of life. For example, Cutter [7] defines it as 'an individual's happiness or satisfaction with life and environment including needs and desires and other tangible and intangible factors which determine overall well being'. For Kline [8], quality of life, at a minimum, needs to measure the ability of citizens to get adequate health care, housing, child care, public safety and education. Increasingly, quality of life is being broadly regarded as an essential element of sustainability. This is so because efforts to promote sustainable development policies are unlikely to be fruitful if they impinge too severely on perceptions of humans' well-being. It is argued that there is little point in trying to implement sustainable systems if they detract from quality of life of the people in these systems [9]. This is very much in evidence in Ireland's current (2007-2013) National Development Plan entitled Transforming Ireland - A Better Quality of Life for All. Clearly implicit in this plan is the notion that it is imperative to link development policies with measures, such as spatial planning, that maintain or enhance quality of life.

Consequently, there is a strong need to devise robust tools that assess quality of life in the context of sustainable development. Not only is there little consensus on what exactly quality of life is but its measurement from a sustainable development perspective also has received very little attention. Some indicators are easier to identify and maintain than others. However, many indicators of quality of life are qualitative in nature and may be more difficult to measure [10]. Wheeler's [10] review of indicators used by the municipal government in Jacksonville, Florida in 1986 and more recent work on the Pierce County Quality of Life Benchmark Project [11] are noteworthy. At the local level in UK, Bristol City Council has very successfully developed quality of life indicators for the city in recent years. Local Agenda 21 Strategy for Bristol provides 'a frame-work and set of principles by which the city can move into a more sustainable future' [12].

Chapter 40 of Agenda 21 [13] called for the development of indicators for sustainable development and since then they have become a key tool for assessing sustainability. A sustainability indicator 'captures and measures a particular aspect of sustainability policy in an easily communicable form, allowing monitoring and subsequent 'steering' of policy, whether by internal management or 
external political pressure' [14]. The use of sustainability indicators can be very beneficial. For example, by measuring specific phenomena in a community - e.g. crime rates, recycling rates, car ownership and green land area - indicators provide vital information about trends in key environmental values and assist in tracking progress towards stated goals. The derivation of quality of life indicators and their observation in urban settings, together with the compilation, analysis and interpretation of related databases, are highly problematic. A primary criticism of sustainability indicators is that they try to encapsulate diverse and complicated processes in a small number of measures [9]. It is alleged that scientists and others are consumed with quantification [15]. Others point out the inherent contradiction regarding sustainability indicators: 'for all their attempt at holism and a desire to incorporate the richness of humankind's complex interrelationships with nature, sustainable indicators are still a classic reductionist set of tools based on quantification' [9]. This brings up the issue of whether simple sustainability indictors can be usefully used to gauge the complex concept, i.e. sustainability [9].

Major criticisms leveled at quality of life projects are that the indicators typically reflect expert opinion about what constitutes quality of life and that citizens' perceptions of the communities and environments in which they live are ignored [3]. Indeed, an emerging body of literature acknowledges that indicators are unlikely to be acceptable or particularly useful, unless they are developed in close consultation with their target populations. In this context, the current prominence of public participation within the sustainable development discourse is particularly noteworthy. The involvement of the public in environmental policy-making is proffered as a means of empowering citizens, enhancing institutional capacity and increasing social responsibility. There is an increasing body of literature that explores approaches to enhance participation and overcome the problems of social exclusion in processes of decision-making [16-18]. Consequently, the process of developing indicators is increasingly viewed as a participatory process that fosters community ownership, builds group credibility and educates participants [19]. Indicators that are not locally determined, locally validated and locally used are of little value [20]. Indicators are potentially empowering tools for monitoring and evaluation, if developed through a community process. Such indicators are also used as a method of engaging the community in working towards shared aims and objectives. On the other hand, imposed indicators can be disempowering tools if deployed by external agents to exert control [21]. They can be used in a manipulative way to deflect attention from issues of more pressing concern to a particular community.

The current research project is situated in the contemporary movement of critical social science which aims at examining issues of quality of life and sustainability from the perspective of the community - the 'non-expert voices' [22]. It is part of an emerging body of literature [4] that seeks to address quality of life in a holistic way. Primary emphasis is on developing a community-derived set of quality of life indicators for Galway that enable individuals to express what is important to them about their city and to enable citizens to influence decisions and policies based on the results obtained. This participatory approach enhances local democracy and in the process raises awareness of elements of the urban environment that are highly valued by the citizens. The results obtained may be utilised by policy makers to identify, understand and address community needs. Importantly, in the context of this paper, the development and utilisation of such indicators allow for comparisons between different neighbourhoods within cities.

\section{RESEARCH DESIGN}

Galway City was selected as the locus for this research project for a variety of reasons. Situated on Ireland's west coast, Galway is Ireland's third largest urban centre with a population of over 66,000 [23]. The city has extended significantly beyond its administrative boundaries in recent years and 
consequently, the population is considerably greater than that is officially reported. As Ireland's fastest growing city, the real population is rapidly approaching 100,000. At a regional level, within Ireland, the Western Development Commission (a state-sponsored body promoting social and economic development for the west of Ireland) initiated a recent national advertising campaign targeted at attracting workers and industries towards Galway and the west of Ireland to avail of improved 'quality of life'. Press releases from their 'Look West' campaign include: 'Living in the West can give you 16 extra hours a week to enjoy' and 'Much shorter commuting and 50\% cheaper housing make compelling case to Look West'. It is clear that the notion of quality of life is a major factor in sustaining economic development in the Galway region.

The demographic profile of the city has changed dramatically over the past 20 years or so. The city is fast growing, increasingly multicultural and youthful. From 2002 to 2005, the city registered an increase of $15 \%$ in population, well above the national average of 9\% [23]. The dynamic growth rate is reflected in the age profile of the city and county with nearly half the population under 24 years old. This figure is influenced strongly by the presence of two higher education institutes in the city, the National University of Ireland, Galway and the Galway Mayo Institute of Technology. Galway is a multicultural city with approximately $10 \%$ of the population being foreign national [24], most of whom are of White background of eastern European origin but with other significant minority elements belonging to Black and Asian ethnic groups. Significant elements of Galway's economy include the construction and services sectors. This reflects the Irish economy as a whole with both sectors seen as key drivers of the Celtic Tiger success [25]. The ICT industry has a significant presence in Galway. It is dominated by a few large multi-national operations, namely, Hewlett-Packard and Nortel. There is also a strong cluster of medical technology companies in the city with world lenders in the sector, such as Medtronic and Boston Scientific, attracted by the skill levels of the work-force as well as the high quality of life that prevailed there. Many of the multi-nationals present in Galway are heavily involved in research and development very often in conjunction with the university and other educational institutes [26]. Other growth sectors in Galway city are retailing and catering. Though renowned nationally for its high quality of life, the general growth of Galway has brought with it a multitude of problems including insensitive building development, soaring house prices and traffic problems. For example, the average cost of a new dwelling in Galway City in 2000 was $€ 163,824$; however, by the year 2005, the average cost of a new dwelling had risen to $€ 274,905$ [27].

In the course of formulating a local process of sustainable development in 2000, Galway City Council, the city's municipal authority, established a range of indicators to monitor and promote progress towards specific economic, social and cultural goals. For example, three indicators were developed to measure progress towards the City Development Board's objective of 'a safe and healthy city'. These indicators are (a) number of crimes per annum, (b) waiting time for medical and surgical services and (c) membership of sports clubs. The indicators cited in the strategy are based on quantitative data that are readily available to the municipal authority and do not include the more general liveability and quality of life issues associated with urban areas. For all of these reasons, Galway was regarded as an excellent laboratory to develop and assess quality of life indicators.

Focus group discussions were used initially to enable the public to identify and collaboratively discuss quality of life issues deemed pertinent to living in Galway and to formulate indicators that would capture that quality of life. Nine focus groups were conducted with groups representing school children, third level students, the chamber of commerce, retired citizens as well as a variety of resident's and community organisations. These groups were drawn from areas all across the city and they afforded the opportunity to seek the opinions of a broad cross-section of citizens. 
A schedule of questions was developed prior to the focus group meetings. Sessions lasted approximately 1-2 hours. Each focus group session was digitally recorded and transcribed.

Nine key quality of life themes emerged from the focus groups: transport, size of the city, sense of community, identity, amenities and facilities, planning and development, environment, economic vitality and social well-being. When these results were compared with pre-existing local authority indicators, a number of gaps with regard to quality of life indicators in Galway City were revealed. For example, while the local authority has data outlining the amount and size of green areas available within the city boundary, participants in the focus groups expressed strong opinions about quality and usage of these green areas, as well as their accessibility, all of which were deemed to be more important than the actual size of the green areas, as far as they were concerned.

The community-derived themes were investigated and tested further in the second stage of the research, a questionnaire survey carried out in Spring 2006. This extensive survey sought to investigate quality of life in the respondents' neighbourhoods, as well as in the city as a whole, and to produce quantitative data for statistical analysis and comparative research. In all, 200 people were interviewed across five city neighbourhoods. The aim of the survey was to establish baseline information about quality of life in Galway City. The topics contained within the questionnaire were based on issues identified by the citizens of Galway in the focus group stage of research, and they covered a wide range of quality of life issues, including perceptions of community, crime, facilities, environmental and economic aspects of life in the respondents' neighbourhoods and throughout the city. In addition to issues identified through the focus groups, topics were also derived from quality of life studies, such as Bristol City's Annual Quality of Life Reports [12] and the European Urban Audit Perception Survey [28]. The questionnaire also contained questions designed to measure the concept of satisfaction as a measure of subjective well-being. Measuring satisfaction with elements of individuals' lives, including health, family, employment, accommodation, social life and standard of living was attempted. The questionnaire also had open-ended questions to assess qualitative aspects of quality of life. In addition to questions relating to quality of life, the final section of the questionnaire survey covered demographic and household characteristics of the sample population. Administering each questionnaire took approximately 15 minutes. In accordance with the goals of sustainable development, the face-to-face format of the questionnaire survey and use of visual aids meant that individuals traditionally marginalised from conventional written questionnaire surveys, such as functionally illiterate persons were included. Galway City is divided into 22 electoral divisions (EDs). Five of these were pre-selected on the basis that they included a diverse range of socio-economic classes, as evident from 2002 Census data. A nested random sample of 200 homes was drawn from these five EDs in rough proportion to their population (Table 1).

For the entire Galway sample, the questionnaire respondents were found to be $48.5 \%$ male and $51.5 \%$ female. This is broadly in line with the 2002 national census data which revealed that the city's population was comprised of $47.1 \%$ males and $52.9 \%$ females in 2002 . As much as $63 \%$ of the respondents were aged $15-44$ years and only $7 \%$ were $65+$ years of age. These figures reflect Galway's relatively young population, as the 2002 census data reveals that $25.9 \%$ of Galway City's population was aged 15-24 years and 31\% was aged 25-44 years [29]. Almost $88 \%$ of the questionnaire respondents had second level leaving certificate, or third level educational qualification. This figure directly relates to the relatively young age structure of the respondents. The 2002 national census shows that recent generations are more educated. The percentage of the Galway population (aged 15 or above) who completed their education with a third level qualification was $40.8 \%$ in comparison with the national figure of $26 \%$ [29]. 


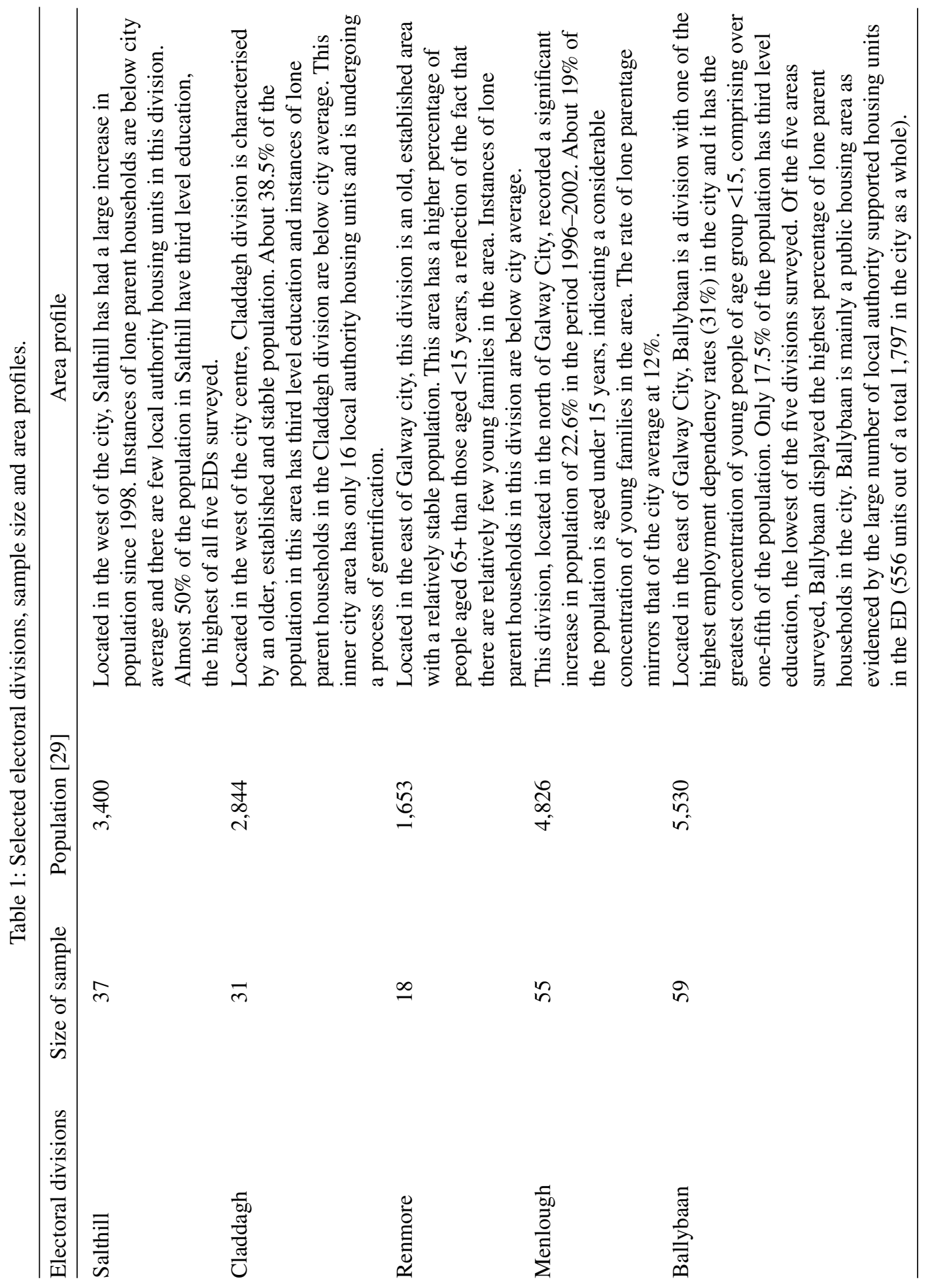


Table 2: Social dimensions of quality of life in Galway.

\begin{tabular}{|c|c|c|c|c|c|c|}
\hline \multirow[b]{2}{*}{ Social dimensions } & \multicolumn{5}{|c|}{ Electoral divisions } & \multirow[b]{2}{*}{ Galway City } \\
\hline & Salthill & Claddagh & Renmore & Menlough & Ballybaan & \\
\hline $\begin{array}{l}\text { Satisfied with } \\
\text { neighbourhood (\%) }\end{array}$ & 97.3 & 96.8 & 88.9 & 94.6 & 83.0 & 91.5 \\
\hline $\begin{array}{l}\text { Satisfied with degree } \\
\text { of social integration }(\%)\end{array}$ & 51.4 & 58.1 & 33.3 & 63.6 & 61.1 & 57.0 \\
\hline $\begin{array}{l}\text { Expressing trust in locally } \\
\text { elected officials (\%) }\end{array}$ & 35.1 & 45.1 & 50.0 & 40.0 & 37.5 & 40.1 \\
\hline $\begin{array}{l}\text { Actively engaged in } \\
\text { community activity (\%) }\end{array}$ & 29.7 & 29.1 & 27.8 & 18.2 & 13.8 & 21.6 \\
\hline $\begin{array}{l}\text { Feeling they can } \\
\text { influence decisions } \\
\text { affecting local area (\%) }\end{array}$ & 45.9 & 61.3 & 50.0 & 63.7 & 48.2 & 50.3 \\
\hline
\end{tabular}

\section{REALITY CHECK: QUALITY OF LIFE ACROSS GALWAY CITY}

\subsection{Social aspects of quality of life in Galway}

Social aspects of quality of life identified by citizens of Galway during the focus group stage of the research and subsequently tested through the questionnaire survey encompassed a variety of topics including: satisfaction with neighbourhood, degree of social integration, trust in elected representatives, degree of civic engagement and sense of empowerment. Salient results are summarised in Table 2. Overall, $91.5 \%$ of all respondents are 'fairly satisfied' or 'very satisfied' with their neighbourhoods as a place to live. Respondents from all the five EDs express high levels of satisfaction with their neighbourhoods, although there are significant variations across neighbourhoods in the proportions who are 'very satisfied' with their neighbourhood as a place to live (Fig. 1). When questioned about sense of belonging to their neighbourhoods, Menlough and Ballybaan had the highest percentage of respondents who did not feel that they belonged to their respective neighbourhoods. Both of these areas have high levels of respondents who have lived in their areas for less than two years. This is attributable in part to the rapid expansion of these neighbourhoods in recent years. It is also due in large measure to the relatively high proportion of the population in these areas who live in rented accommodation and who are typically more geographically mobile than residents who own their accommodation. Even in the case of the latter, many see these homes as a first step on the housing ladder and aspire to move out in due course when they get to a stage where they can afford more salubrious housing in other locations. Considering the highly mobile nature of the population, the issue of not knowing ones' neighbours is a major factor in perceptions of trust and integration within these two EDs. Comments like 'People here keep to themselves, it's very hard to make friends' reflect a prevailing obstacle to neighbourliness in the two localities. With very many people moving on in due course, they are not particularly interested in building community relations.

With regard to social integration, 57\% of respondents feel that 'non-nationals who live in Galway are well integrated'. Over $28 \%$ feel that there was either 'a lot of tension' or 'some tension' between different racial and ethnic groups in the city. The residents of Ballybaan and Menlough regard non-nationals to be well integrated, more so than the respondents from the other EDs. For example, 


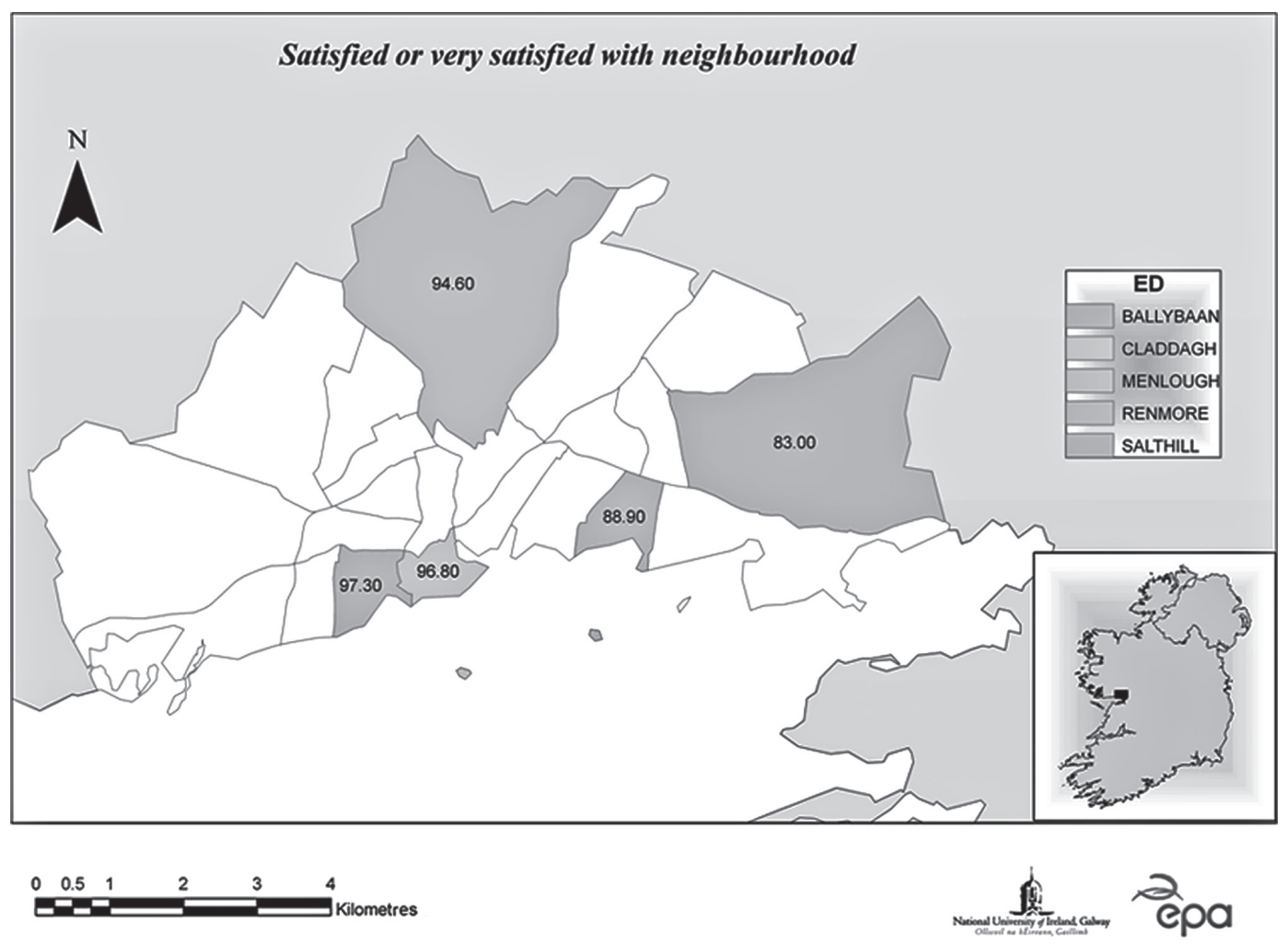

Figure 1: Location of Galway (inset) and satisfaction levels with neighbourhoods in the electoral divisions surveyed.

this sentiment is not strongly reflected in the older settled neighbourhood of Renmore, where only $33 \%$ of the respondents share this view. On average, across all five divisions, $82 \%$ of the respondents feel that people from different backgrounds get on well in the area, suggesting that there is a good degree of social integration. Respondents from Renmore share this view less enthusiastically than those in the other EDs. It appears that older settled communities, such as Renmore, are somewhat ill at ease with the significant inflows of what are locally and sometimes derogatively referred to as 'blow-ins', especially when these are foreign national of African, Asian and East European origin. Such inflows are a relatively new phenomenon in Galway and older people are generally not accustomed to meeting and socialising with foreign nationals.

With regard to volunteerism and involvement in community activities, a vast majority (78\%) of the respondents across the city have not been involved in any local community activities over the previous year. This is consistent with a general decline in volunteerism and civic engagement in Ireland over recent years. It is also consistent with a recent study of housing in Galway which found that the residents had very little involvement in the management of their estates [30]. In the current research, only $4 \%$ of the respondents are involved on a weekly basis in local community group activities, $80 \%$ are involved in residents' associations and $13.3 \%$ are involved in local active retirement groups. Respondents from the older settled district of Renmore have the highest participation rate of the five EDs surveyed in community activities. Older retired residents may regard such activities as a social outlet and a useful way of spending their additional leisure time. Conversely, Ballybaan 
and Menlough display the lowest level of active interest in local issues and in community group participation. Ballybaan has the lowest percentage of residents who claim to be active in trying to influence issues of local concern: $61 \%$ feel that they are neither active nor interested in such matters and only $14 \%$ were involved, to any extent during the last year, in a community group (primarily residents' associations), again marginally the lowest of the EDs surveyed. The general picture emerging in the case of these two suburbs is that the citizens have insufficient long-term interests in their neighbourhoods to engage in community-centred activities. A prevailing sense of social anomie is reflected in the following statement: 'The Residents Association is pretty much dormant. Attendance has been poor, no-one seems to care'. Indeed, a number of respondents across the five EDs referred to a perceived trend in the erosion of community spirit across the city as a whole, mirroring the trend that has been identified by Selman's [31] research on sustainability in local areas. Low levels of participation in community activities is also linked to a widespread sense of powerlessness with only $50 \%$ of the population feeling that they can influence decisions affecting their local areas. This problem is undoubtedly compounded by the low level of trust in locally elected members of the city council. Respondents in the older residential areas of Renmore and Claddagh have the highest levels of trust in locally elected officials but even in these EDs these levels are less than $50 \%$. In all five EDs, a substantial percentage feel that the question of trust in local politicians is not applicable to them as they tend to feel disenfranchised and tend not to know who their locally elected representatives are. The low level of trust in the municipal authority is mirrored in the fact that only one of the 59 respondents from Ballybaan visited the city council in the previous year. This lack of engagement with municipal authority indicates a strong need on the part of the municipal authority to promote participatory governance practices especially amongst poorer less well-educated communities.

\subsection{Environmental aspects of quality of life in Galway}

Arising from the focus group discussions, a variety of environmental indicators were identified by the citizens of Galway as key variables influencing quality of life. They were examined in the questionnaire survey also. The results are summarised in Table 3. Overall, $70 \%$ of the respondents are satisfied with the amount of green spaces in their area, with $68.3 \%$ who are satisfied with the quality of the green spaces also. In Renmore, $94 \%$ of the respondents are satisfied with the quantity of green space in that ED. This is the highest degree of satisfaction reported amongst all five divisions. This is not at all surprising as this suburb was built in the 1960s and 1970s when housing densities in many urban areas were much less than standards prevailing now. Also a very active Renmore residents association at that time sought expert advice on urban planning matters and vigorously pursued the provision of parks, sports fields and other green spaces with the planning authority. In this regard, Renmore is testimony to the value of communities engaging with local government in promoting the betterment of their neighbourhoods. However, some older residents feel that there are some improvements which could be made for their benefit, for example, 'There were benches in the park, but they were burnt down. There's nowhere to sit. If you are an older person taking a walk, you can't find a place to rest. There should be more benches'. Despite having a large amount of green space in Renmore, the majority of the respondents only use this space from once a week to once a month. In comparison, $43 \%$ of the respondents from Salthill claim they use their local green spaces more than three times a week. About $90 \%$ of the respondents from Claddagh feel satisfied with the amount of parks and green space in their local area. However, 25\% are unhappy with the quality of the green space available. According to the Galway City Atlas [32], Menlough has at least three amenity areas of over 2 ha each. Nevertheless, over one quarter of the respondents are dissatisfied with the amount of green spaces in their area. This is the second highest level of 
Table 3: Environmental dimensions of quality of life in Galway.

\begin{tabular}{lcccccc}
\hline \multirow{2}{*}{$\begin{array}{l}\text { Aspects of } \\
\text { quality of life }\end{array}$} & Salthill & Claddagh & Renmore & Menlough & Ballybaan & Galway City \\
\cline { 2 - 6 } & 75.7 & 90.3 & 94.4 & 69.1 & 49.2 & 70.0 \\
\hline $\begin{array}{c}\text { Satisfied with the amount } \\
\text { of green spaces (\%) }\end{array}$ & 64.9 & 80.7 & 77.8 & 58.1 & 66.7 & 67.2 \\
$\begin{array}{c}\text { Satisfied with } \\
\text { streetscape (\%) }\end{array}$ & 86.5 & 87.1 & 77.8 & 83.7 & 86.5 & 85.0 \\
$\begin{array}{c}\text { Satisfied with waste } \\
\text { recycling (\%) }\end{array}$ & 32.4 & 25.8 & 5.6 & 3.6 & 6.8 & 13.5 \\
$\begin{array}{c}\text { Perceiving dog fouling } \\
\text { as a serious problem (\%) }\end{array}$ & 8.1 & 9.7 & 0.0 & 14.5 & 6.8 & 9.0 \\
$\begin{array}{c}\text { Perceiving litter as } \\
\text { a serious problem (\%) }\end{array}$ & & & & & & \\
\hline
\end{tabular}

dissatisfaction regarding the amount of green spaces, next to Ballybaan. The respondents from Menlough have one of the lowest levels of usage of their green spaces, $38 \%$ claim that they never use it which is the highest of the five divisions. Over one quarter of the respondents in Ballybaan feel that they had no green space in their areas, the highest of all five divisions. Ballybaan has the lowest percentage of respondents who use parks and green spaces more than once a week. About $41 \%$ of the respondents are dissatisfied with the amount of green and park spaces to which they had access. The overall picture emanating from the analysis of satisfaction with green spaces is that the provision of such areas needs careful consideration. Space alone is clearly insufficient. The accessibility and quality of green spaces are of paramount importance.

Almost $60 \%$ of all respondents expressed the view that Galway was a clean city. Air pollution in the city was not perceived as a problem by $81.9 \%$ of all respondents. In contrast, litter is viewed as a problem by $42 \%$ of the respondents although only $9 \%$ see it as a serious problem. In Ballybaan, $40 \%$ of the respondents feel that there is a problem with litter in their neighbourhoods. One-half of the respondents in Renmore feel that there is a problem with litter in the area and $44 \%$ feel that dog fouling is a problem in their neighbourhoods. In Menlough, $46 \%$ of the respondents feel that there is a problem with litter in their neighbourhoods. In the Salthill region, only $16 \%$ of the respondents feel that litter is a serious problem. However, over $60 \%$ of the residents in Salthill regard dog fouling as a problem, with many citing it as a serious problem. Similar issues emerged in Claddagh, where $76 \%$ of the respondents feel that dog fouling poses a substantial problem in their neighbourhoods. That litter and dog fouling should feature prominently in the Claddagh and Salthill is not surprising as these EDs have extensive seaside promenades that are very popular amenities.

In general, there is a widespread satisfaction with the recycling services provided for their local areas (see Table 3). However, several respondents from Ballybaan area commented that there should be some differentiation made in the cost of recycling services between parts of the city: 'I feel there should be a difference in the amount we pay for bins, between the rich and poor'.

\subsection{Economic aspects of quality of life in Galway}

Table 4 depicts the proportion of respondents satisfied with economic dimensions of quality of life in Galway by ED. These economic dimensions were highlighted as key aspects of quality of life in 
Table 4: Economic dimensions of quality of life in Galway.

\begin{tabular}{lcccccc}
\hline \multirow{2}{*}{$\begin{array}{l}\text { Aspects of } \\
\text { quality of life }\end{array}$} & Salthill & Claddagh & Renmore & Menlough & Ballybaan & Galway City \\
\cline { 2 - 6 } & Satisfied with \\
$\begin{array}{c}\text { availability of } \\
\text { employment (\%) }\end{array}$ & 43.2 & 45.2 & 38.9 & 41.8 & 35.1 & 40.4 \\
$\begin{array}{c}\text { Satisfied with } \\
\text { affordability of } \\
\text { housing (\%) }\end{array}$ & 16.2 & 9.7 & 27.8 & 29.1 & 38.6 & 26.2 \\
\hline
\end{tabular}

the previous focus group stage of research. Surprisingly, in an age of high employment growth and in a city in which economic conditions are relatively buoyant, with historically low levels of unemployment, approximately one third of all respondents disagree with the statement that it is easy to obtain employment in Galway City. This probably reflects the highly competitive nature of much of the local labour market, with very many prospective employers requiring advanced level skills to adequately meet their job specifications. Finding good housing in Galway City is regarded as problematic by $66 \%$ of the respondents. Many found it particularly challenging to acquire suitable housing at an affordable price and only $26 \%$ of the respondents were satisfied with the affordability of housing in the city. Interestingly, $75 \%$ of all respondents who 'strongly' or 'somewhat' agree with this statement lived in privately-rented accommodation but $82 \%$ of the respondents living in privatelyowned accommodation somewhat or strongly disagree with the statement. The housing problem is most acutely felt in the Claddagh and Salthill, where only $10 \%$ and $16 \%$ respectively, regarded it as 'easy' to find good housing at a reasonable price. Only in Ballybaan did a substantial percentage $(38.6 \%)$ of respondents report it easy to find good housing at a reasonable price but this probably reflects the high level of public housing provision in that area.

\subsection{Personal quality of life issues}

In addition to questions relating to quality of life issues at the local neighbourhood level and at the wider city level, the respondents were asked to rank (on a scale of 1-10 where 1 indicates dissatisfaction and 10 indicates very satisfied) their satisfaction with personal quality of life factors. In contrast to the quality of life aspects already discussed in this paper which were initially identified by the public through focus groups, this question is derived from the European Urban Audit Perception Survey [28] and is designed to facilitate future cross-European quality of life comparative research. The results indicate high levels of personal satisfaction on most counts for the city as a whole. However, significant variations are apparent by EDs across several of the parameters (Table 5). For example, levels of satisfaction with current job display a wide range of responses. Very high rates of job satisfaction are found in Salthill and Claddagh. The levels of satisfaction appear relatively low in Renmore but this is clearly related to the high proportion of the respondents who regard this question as not relevant to them, primarily because they are in retirement. The lowest percentage of respondents indicating high levels of satisfaction are in Menlough and Ballybaan where unemployment levels are relatively high. Satisfaction with levels of educational attainment varies significantly amongst the EDs and matches to a considerable extent the pattern in respect to job satisfaction. Very high levels of satisfaction with one's education are to be found in Salthill and to a lesser extent in Claddagh. In contrast, very significant proportions of respondents are dissatisfied with their educational attainments in Ballybaan. There is a 
Table 5: Personal dimensions of quality of life in Galway.

\begin{tabular}{lcccccc}
\hline \multirow{2}{*}{$\begin{array}{l}\text { Aspects of } \\
\text { quality of life }\end{array}$} & Salthill & Claddagh & Renmore & Menlough & Ballybaan & Galway City \\
\cline { 2 - 6 } & 67.5 & 64.5 & 50.0 & 47.3 & 42.4 & 52.5 \\
\hline $\begin{array}{l}\text { Satisfied with } \\
\text { current job (\%) }\end{array}$ & 81.0 & 61.3 & 38.9 & 58.1 & 25.5 & 51.5 \\
$\begin{array}{l}\text { Satisfied with educational } \\
\text { attainment (\%) }\end{array}$ & 83.7 & 77.5 & 77.8 & 69.1 & 49.1 & 68.0 \\
$\begin{array}{l}\text { Satisfied with } \\
\text { accommodation (\%) }\end{array}$ & 78.3 & 61.4 & 72.2 & 63.6 & 47.5 & 62.0 \\
$\begin{array}{l}\text { Satisfied with social } \\
\text { life (\%) }\end{array}$ & 81.0 & 74.3 & 50.0 & 78.2 & 76.2 & 75.0 \\
$\begin{array}{l}\text { Satisfied with health (\%) } \\
\text { Satisfied with } \\
\text { family life (\%) }\end{array}$ & 81.0 & 77.4 & 77.8 & 70.9 & 67.7 & 73.5 \\
$\begin{array}{l}\text { Satisfied with } \\
\text { standard of living (\%) }\end{array}$ & 97.3 & 74.3 & 72.3 & 80.0 & 52.6 & 73.7 \\
\hline
\end{tabular}

good degree of satisfaction with accommodation in the city as a whole with particularly high levels of satisfaction in Salthill, Claddagh and Renmore and to a somewhat lesser extent in Menlough. Ballybaan is the only ED in which less than half of the respondents are highly satisfied with their housing.

Level of satisfaction with one's social life also is generally high except in Ballybaan where once again less than half of the population are highly satisfied on this count. Salthill and Renmore residents display the highest levels of satisfaction with their social lives with many respondents indicating active interests in many social and recreational pursuits. Satisfaction with one's health is high across the city with the notable exception of Renmore where only one-half of the respondents are very satisfied with their health in comparison with $81 \%$ in Salthill and $75 \%$ across the city as a whole. Probably, the anomalous situation in Renmore is attributable in large measure to the relatively older age-profile of the population in that ED. The level of satisfaction with one's family life is generally high across the city. In Salthill, Claddagh and Renmore, approximately $80 \%$ of the population are very satisfied with their family life. Residents of Ballybaan and Menlough also feature well in this parameter with approximately $70 \%$ of them highly satisfied with family life.

Satisfaction with standard of living is high in the city as a whole with $74 \%$ expressing themselves very satisfied in this regard. A very pronounced degree of satisfaction prevails in Salthill where as many as $97 \%$ are highly satisfied with their living standards. Ballybaan is in striking contrast to Salthill with very many respondents not particularly happy with their living standards, although 53\% of Ballybaan residents also are highly satisfied with their standard of living. In general, life in Galway is satisfactory for the overwhelming majority of its population with as many as $98 \%$ of the respondents of that view. This view is strongly held throughout the city with only minor variations apparent from one ED and to another.

\section{DISCUSSION: LINKING QUALITY OF LIFE WITH APPROPRIATE POLICY ACTION AND DECISION-MAKING}

The baseline case study of Galway City reveals significant variations in quality of life across neighbourhoods. The results show high levels of satisfaction with many elements of quality of life 
in Galway. However, they also reveal a number of areas of dissatisfaction, and certain issues are shown to vary in significance from one ED to another. Some issues are specific to certain locations only. A clear conclusion is that quality of life is unequivocally influenced by location. This research also demonstrates the essential need to understand the local context in which quality of life indicators are formulated. This marks a considerable shift away from the more technical perspective on indicator development that has prevailed in the past [14].

Indicators are not a substitute for action. However, they clearly create social knowledge and the connections that are needed for 'meaningful action' [33]. It is vital that indicators are coupled with ongoing actions to bring about change [33]. In linking quality of life considerations with appropriate policy action and decision-making, it is clear from the results of this research that indicators need to be grounded in the reality of the locality. Neglecting to examine neighbourhood contextual factors limit the applicability of quality of life research and reduce the long-term effectiveness of policy interventions that are contingent on the transformation of people's contextualised values and practices.

The data generated through this project may be used by the municipal authorities and other bodies to assess service provision, and other quality of life indicators and to plan interventions accordingly. For this purpose, Table 6 summarises the contribution of an array of variables examined in the course of this study to quality of life. Certain variables are clearly shown to negatively impact quality of life throughout the city and other factors loom large only in particular neighbourhoods. Though trust in

Table 6: Variables influencing quality of life by neighbourhood.

\begin{tabular}{|c|c|c|c|c|c|}
\hline $\begin{array}{l}\text { Examples of quality of life } \\
\text { indicators examined }\end{array}$ & Salthill & Claddagh & Renmore & Menlough & Ballybaan \\
\hline \multicolumn{6}{|l|}{ Social aspects } \\
\hline $\begin{array}{l}\text { Perception of sense of belonging } \\
\text { in a neighbourhood }\end{array}$ & $\sqrt{ }$ & $\sqrt{ }$ & $\sqrt{ }$ & $\mathrm{X}$ & $\mathrm{X}$ \\
\hline $\begin{array}{l}\text { Satisfaction with neighbourhood } \\
\text { as a place to live }\end{array}$ & $\sqrt{ }$ & $\sqrt{ }$ & $\sqrt{ }$ & $\sqrt{ }$ & $\sqrt{ }$ \\
\hline $\begin{array}{l}\text { Volunteerism and involvement } \\
\text { in local groups }\end{array}$ & - & - & - & $\mathrm{X}$ & $\mathrm{X}$ \\
\hline Trust in neighbours & $\sqrt{ }$ & $\sqrt{ }$ & $\sqrt{ }$ & $\sqrt{ }$ & $\sqrt{ }$ \\
\hline Trust in locally elected officials & $\mathrm{X}$ & $\mathrm{X}$ & - & $\mathrm{X}$ & $\mathrm{X}$ \\
\hline Perceptions of integration & - & $\sqrt{ }$ & $\mathrm{X}$ & $\sqrt{ }$ & $\sqrt{ }$ \\
\hline \multicolumn{6}{|l|}{ Environmental aspects } \\
\hline Perceptions of green areas & $\sqrt{ }$ & $\sqrt{ }$ & $\sqrt{ }$ & $\mathrm{X}$ & $\mathrm{X}$ \\
\hline Recycling service & $\sqrt{ }$ & $\sqrt{ }$ & $\sqrt{ }$ & $\sqrt{ }$ & $\sqrt{ }$ \\
\hline Litter & - & $\mathrm{X}$ & $\mathrm{X}$ & $\mathrm{X}$ & $\mathrm{X}$ \\
\hline Dog fouling & $\mathrm{X}$ & $\mathrm{X}$ & - & - & - \\
\hline \multicolumn{6}{|l|}{ Economic aspects } \\
\hline Perception of standard of living & $\sqrt{ }$ & $\sqrt{ }$ & $\sqrt{ }$ & $\sqrt{ }$ & $\mathrm{X}$ \\
\hline Availability of affordable housing & $\mathrm{X}$ & $\mathrm{X}$ & - & - & $\sqrt{ }$ \\
\hline Ease of employment attainment & - & - & - & - & - \\
\hline
\end{tabular}

$X$ : negative; $\sqrt{ }$ : positive; -: neutral. 
neighbours is high throughout the city, for example, trust in local politicians is notably not so. This appears to be having the effect of alienating citizens from local political processes and accentuating a decline in level of civic engagement as reflected in low levels of involvement in community activities. This suggests a need for the City Council to proactively involve communities in decision-making in relation to their neighbourhoods.

For the municipal authority and other relevant bodies, these indicators portray a 'grass roots perspective' of how citizens rate their cities, i.e. an evaluation of the liveability of Galway City. In addition, the process of developing these indicators raises awareness about a wide range of quality of life issues. Indeed, central to this project is the engagement of a local municipal authority with citizens and communities to gather relevant information and shape sustainable development practices. This is in line with sustainable development discourse that places heavy emphasis on the need to develop more democratic mechanisms for decision-making. In this sense, regardless of the set of quality of life indicators generated, the actual process of deriving the information is an end in itself. Community-derived indicators allow individual citizens and communities to express the most important determinants of quality of life for them. The data generated in the course of this study affords an opportunity for targeted interventions by relevant authorities. Furthermore, these indicators may be monitored by the municipal authority and other interested bodies on an ongoing basis to assist in ensuring that quality of life in the city of Galway is sustained in the longer term.

The results of this paper are relevant not only for policy-makers and communities in the Irish context but for academics and decision-makers elsewhere. The development of a universal set of indicators for sustainability is ideal for national planning and international comparative purposes. However, as we have seen in the case of Galway City, huge differences in geographical, economic and socio-cultural contexts exist which constrain the development of a universal set of sustainability indicators. This research project has focused on developing a methodology for formulating and testing quality of life indicators that are context-specific. The methodology as developed is sufficiently robust and adaptable to be transferable to other municipal settings in Ireland and elsewhere. The commitment in Ireland's current National Development Plan 2007-2013 to achieve 'a better quality of life for all' though highly commendable is very challenging as development outcomes tend to be spatially variable, and many outcomes, such as commuting times and affordability of housing can adversely impact quality of life of many people. It is proposed that the contextspecific methodology for measuring quality of life as outlined in this paper represents an appropriate tool for evaluating the Plan's outcomes in terms of impacts on local communities.

\section{ACKNOWLEDGEMENTS}

The authors would like to thank the EPA/ERTDI for their generous support for the research presented in this paper through a research grant (research grant \# 2004-SD-FS-23). The research would not have been possible without the cooperation of all those who participated in the questionnaire survey and focus group discussions.

\section{REFERENCES}

[1] Moore, N. \& Scott, M., Towards a Sustainable Future in Renewing Urban Communities: Environment, Citizenship and Sustainability in Ireland, Ashgate: Aldershot, 2005.

[2] The Economist, The World in 2005, www.economist.com, accessed on 14/05/2006, 2005.

[3] Moller, V., Monitoring quality of life in cities: the Durban case. Development Southern Africa, 18(2), pp. 217-222, 2001.

[4] Swain, D. \& Hollar, D., Measuring progress: community indicators and quality of life. International Journal of Public Administration, 26(7), pp. 789-814, 2003. 
[5] Rogerson, R.J., Quality of life and city competitiveness. Urban Studies, 36(5-6), pp. 969-985, 1999.

[6] Myers, M., Building knowledge about quality of life for urban planning. Journal of the American Planning Association, 54, pp. 347-358, 1988.

[7] Cutter, S.L., Rating Places: A Geographers View on Quality of Life, Association of American Geographical Research Publishers: USA, 1985.

[8] Kline, E., Indicators for sustainable development in urban areas. How Green is the City?, eds D. Devuyst, L. Hens \& W. De Lannoy, Columbia: USA, pp. 275-298, 2001.

[9] Bell, S. \& Morse, S., Sustainability Indicators, Earthscan: London, 1999.

[10] Wheeler, S., Planning for Sustainability: Creating Livable, Equitable, and Ecological Communities, Routledge: UK, 2004.

[11] Devuyst, D., Hens, L. \& De Lannoy, W., (eds), How Green is the City?, Columbia: USA, 2001.

[12] Bristol City Council, Indicators of Quality of Life in Bristol, www.bristol-city.gov.uk, 2005.

[13] United Nations Conference on Environment and Development (UNCED), Agenda 21 - Action Plan for the Next Century, UNCED: Rio de Janeiro, 1992.

[14] Rydin, Y., Holman, N. \& Wolff, E., Local sustainability indicators. Local Environment, 8(6), pp. 581-590, 2003.

[15] MacRae, R.J., Hill, S.B., Henning, J. \& Mehuys, G.R., Agricultural science and sustainable agriculture: a review of existing scientific barriers to sustainable food production and potential solutions. Biology, Agriculture and Horticulture, 6, pp. 173-219, 1989.

[16] Healy, P., Collaborative Planning, Palgrave: UK, 1997.

[17] Lovan, W.R., Murray, M. \& Schaffer, R., (eds), Participatory Governance: Planning, Conflict Mediation and Public Decision-Making in Civil Society, Ashgate: Aldershot, 2004.

[18] Murray, M., Greer, J. \& Sterrett, K., The public value of public involvement: insights from participatory village planning in Ireland. Administration, 53(1), pp. 3-15, 2005.

[19] Fahy, F. \& Ó Cinnéide, M., Community-based quality of life indicators for urban areas as derived in Galway City, Ireland. The Sustainable City, eds U. Mander, C.A. Brebbia \& E. Tiezzi, WIT Press: Boston, 2006.

[20] Rogers, M., Social sustainability and the art of engagement. Local Environment, 10(2), pp. 109-124, 2005.

[21] Kenny, S., Evaluation and community development: mantras, challenges, and dilemmas. Paper presented at the 2002 Australasian Evaluation Society Conference, Wollongong, 30 October-1 November 2002.

[22] Hobson, K., Thinking habits into action: the role of knowledge and process in questioning household consumption practices. Local Environment, 8(1), pp. 95-112, 2003.

[23] Central Statistics Office. Statistical Bulletin, The Stationery Office: Dublin, 2005.

[24] Central Statistics Office. National Census, CSO: Dublin, 2006.

[25] Kirby, P., The Celtic Tiger in Distress: Growth with Inequality in Ireland, Palgrave: New York, 2002.

[26] Collins, P. \& Grimes, S., Leveraging of Power by Foreign Owned Affiliates of MNCs in Ireland. Presentation to Regional Studies Association, Irish Branch, April 2005.

[27] Department of the Environment, http://www.environ.ie, accessed on 13/09/2006, 2006.

[28] European Urban Audit Perception Survey, www.urbanaudit.org, 2004.

[29] Central Statistics Office. National Census, CSO: Dublin, 2002.

[30] Mahon, M. \& Ó Cinnéide, M., Governance deficits in residential housing estates in Ireland. Urban Studies, 46(1), 2009 (forthcoming). 
[31] Selman, P., Local Sustainability: Managing and Planning Ecologically Sound Places, Chapman: London, 1996.

[32] Galway City Council. Galway City Atlas, Galway City, 2004.

[33] Gahin, R., Veleva, V. \& Hart, M., Do indicators help create sustainable communities. Local Environment, 8(6), pp. 661-666, 2003. 